\title{
ANALYSIS OF THE VACUUM-STEAM DEFROSTING PROCESS OF PLUMS PRE-TREATED WITH DEHYDROFREEZING
}

\author{
Agnieszka Szparaga $^{\mathrm{a}}$, Sławomir Kocira ${ }^{\mathrm{b}}$, Alaa Subr ${ }^{\mathrm{c}}$, Ameer Al-Ahmadi $^{\mathrm{d}}$ \\ a Department of Agrobiotechnology, Koszalin University of Technology, Koszalin, Poland, \\ e-mail: agnieszka.szparaga@ @u.koszalin.pl, ORCID 0000-0001-9153-7783 \\ b Department of Machinery Exploitation and Management of Production Processes, University of Life \\ Sciences in Lublin, Lublin, Poland, e-mail: slawomir.kocira@up.lublin.pl ORCID 0000-0002-2888- \\ 3023
}

${ }^{\mathrm{c}}$ Department of Agricultural Machines and Equipment, College of Agricultural Engineering Sciences, University of Baghdad, Baghdad, Iraq, e-mail: alaa.kamel@ coagri.uobaghdad.edu.iq, ORCID 00000001-5529-9773

${ }^{\mathrm{d}}$ Department of Agricultural Machines and Equipment, College of Agricultural Engineering Sciences, University of Baghdad, Baghdad, Iraq, e-mail: ameer.alahmadi@coagri.uobaghdad.edu.iq, ORCID 0000-0002-9046-9990

* Corresponding author: e-mail: agnieszka.szparaga@tu.koszalin.pl

\begin{tabular}{|c|c|}
\hline ARTICLE INFO & ABSTRACT \\
\hline $\begin{array}{l}\text { Article history: } \\
\text { Received: January } 2020 \\
\text { Received in the revised form: } \\
\text { February } 2020 \\
\text { Accepted: March } 2020\end{array}$ & $\begin{array}{l}\text { The research material was prune plums (Prunus domestica } \text { L.), sub- } \\
\text { jected to osmotic pre-treatment, with variable process time parameters } \\
\text { and osmotic solution concentration. Plums thus fixed were frozen and } \\
\text { stored for } 6 \text { months. At even (monthly) intervals, the product was de- } \\
\text { frosted by the vacuum-steam method, using the s-p-p chamber, until the }\end{array}$ \\
\hline $\begin{array}{l}\text { Key words: } \\
\text { plums, } \\
\text { chamber, } \\
\text { defrosting, } \\
\text { dehydrofreezing, } \\
\text { process }\end{array}$ & $\begin{array}{l}\text { thermocouple indicated a temperature of } 4^{\circ} \mathrm{C} \text { in the sample's thermal } \\
\text { center. In order to study the kinetics of phenomena occurring during the } \\
\text { defrosting process, the chamber was equipped with a measuring system } \\
\text { to enable measurement and recording of temperature changes in time in } \\
\text { the geometric center of the sample, as well as the temperature on the } \\
\text { sample surface. The conducted tests proved that the time of vacuum- } \\
\text { steam defrosting of fruit depended on the amount of water contained in } \\
\text { it. In plums dehydrated in } 45-65 \% \text { sucrose solutions, duration of the } \\
\text { defrosting process was shortened already after three months of frozen } \\
\text { storage. After } 6 \text { months of storage, defrosting of these fruits was twice } \\
\text { as fast as that of control samples. }\end{array}$ \\
\hline
\end{tabular}

\section{Introduction}

Over the past few years, many studies have been conducted worldwide regarding the osmotic dehydration process of fruit and vegetables (Agngeli et al., 2005, Chiralt and Talens, 2005, Kowalska and Lenart, 1999, Kowalska and Lenart, 2005, Lazarides and Mavroudis, 1995, Moreno et al., 2000). However, only a few relate to the combined fixation method, i.e. dehydrofreezing, which aims to take advantage of the benefits of osmotic dehydration and freezing. Combination of processes allows preserving the valuable thermolabile components 
and reduce high energy expenditure. Osmotic substances significantly impact the preservation of the basic values of the raw material, affecting cells of the plant material and making it difficult to orient the water molecules towards the crystal lattice (Kamińska and Lewicki, 2005, Kamińska and Lewicki, 2006, Kowalska and Lenart, 2005, Pałacha and Kamińska, 2001).

It has been proved that during freezing osmotically dehydrated materials, small ice crystals are formed, which do not damage the structure of the plant material, thus limiting the leakage of juice after defrosting (Pałacha and Kamińska, 2001). Achieving microbiological stability, reducing unwanted chemical reactions and cutting transport and storage costs is also important (Konopacka, 2006, Kowalska and Lenart, 2005, Piotrowska and Nowak, 2005).

An important aspect of fixing products is to maintain their highest quality, similar to the properties of the raw material before processing. The quality of the frozen product is closely related to the freezing and defrosting technique (Chiralt and Talens, 2005, Kowalska and Lenart, 2005, Kamińska and Lewicki, 2005, Kamińska and Lewicki, 2006). The best freezing technology and optimal storage conditions do not always guarantee the high quality of the defrosted product. Improper handling during defrosting, or keeping of the product for a prolonged period of time after defrosting, leads to a significant reduction in the quality of defrosted fruit and vegetables, both in industrial conditions and at home (Diakun and Kopeć, 2004, Gruda and Postolski, 1999).

To obtain high quality defrosted product, appropriate defrosting methods are selected, depending on the type of frozen product, and other parameters and requirements, such as the condition of the raw material before freezing or the method of freezing and refrigerated storage. Choosing the right defrosting method is difficult because various factors come into consideration.

There are many methods of defrosting, however, new ways of implementing this process are under research, both modernizing the already used methods and creating new ones (Diakun and Kopeć, 2004,).

This paper is also a continuation of research on the possibility of using a vacuum - steam chamber with an external steam generator in the process of defrosting plums. The chamber was designed and constructed in 2006, at the Faculty of Mechanical Engineering of Koszalin University of Technology, as part of the doctoral dissertation of Dr Eng. Adam Kopeć, entitled "Study of the operational properties of a vacuum chamber with an external steam generator in the process of defrosting meat". However, thus far it has only been used to defrost meat and fish. The first attempts to use the chamber for defrosting other foods included strawberries. Unfortunately, due to the delicate structure of the fruit at the stage of full consumption maturity, achieving satisfactory results in terms of quality was not possible (Diakun and Kopeć, 2004,, Kopeć et al., 2009). The possibility of using this method in the process of defrosting fruit with a different structure and morphology has not yet been studied. Considering the above, the purpose of the work was to determine whether this type of technology may prove useful in the process of defrosting plums.

\section{Material and methods}

The research material was prune plums (Prunus domestica L.). Osmotic dehydration of plum halves was carried out in $35,45,55$ and $65 \%$ sucrose solutions for 1.5 and 3.0 hours at 
Analysis of the vacuum-steam...

$20^{\circ} \mathrm{C}$. The ratio of the mass of raw material to the mass of the osmotic solution was $1: 4$. Dehydration was carried out in an Elpin+ type 357 water bath shaker. After removing the water, the fruits were drained in a sieve for 5 minutes, weighed and packed in plastic (PE) bags, and then frozen in free convection. The weight of each individual sample was $100 \pm 2$ g. Fruits were frozen to $-18^{\circ} \mathrm{C}$ and stored for 6 months. The Gorenje F $61300 \mathrm{DW}$ drawer freezer was used in the freezing process.

At even (monthly) intervals, the product was defrosted by the vacuum-steam method, using the s-p-p chamber, until the thermocouple indicated a temperature of $4^{\circ} \mathrm{C}$ in the sample's thermal center. The s-p-p defrosting method required the first stage to create a vacuum of $10 \mathrm{~Pa}$ in the defrosting chamber, within the range of so-called mean vacuum. The main elements of the station were a vacuum defrosting chamber, steam generator and a vacuum pump. The steam generator was a $1000 \mathrm{~cm}^{3}$ round glass flask placed in a $400 \mathrm{~W}$ laboratory electric heating jacket. The vacuum pump and the steam generator were connected to the chamber with flexible vacuum hoses through manual ball valves.
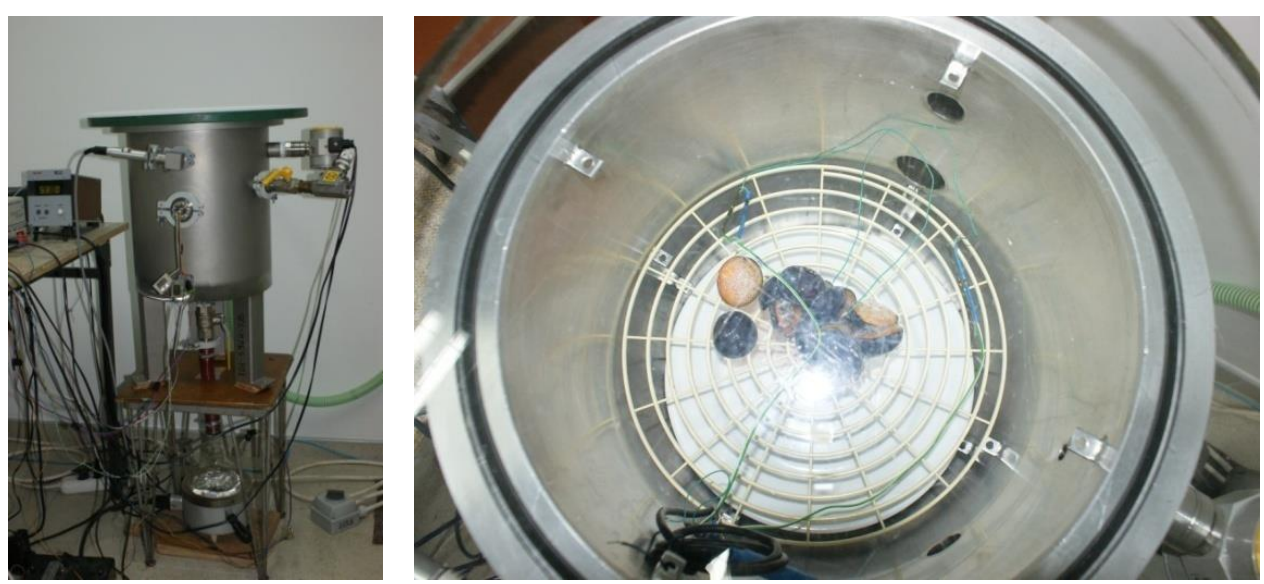

Figure 1. The s-p-p chamber - general view, top view

In order to study the kinetics of phenomena occurring during the defrosting process, the chamber was equipped with a measuring system to enable measurement and recording of:

- the temperature in the geometric center of the sample,

- the surface temperature of the sample.

The temperature was measured using $\mathrm{K}$-type thermocouples $(\mathrm{NiCr}-\mathrm{NiAl})$, with wire diameter $\mathrm{d}=0.2 \mathrm{~mm}$. The measurement error was $\pm 1^{\circ} \mathrm{C}$. Defrosting was carried out in the so-called mean vacuum, approx. $10 \mathrm{~Pa}$. During the process, the water temperature in the steam generator was maintained at approx. $20^{\circ} \mathrm{C}$ (temperature sensor LM 335). The relative humidity of the air in the chamber ranged from 75 to $85 \%$ (humidity sensor HIH -36010 Honeywell). The sensors installed on the stand were connected to a PCI 1710 measurement 
card. The sensor data were properly processed using the LabVIEW programming environment, to enable their registration. The obtained results (temperature distribution as a function of time) were presented in a graphic form using the Matlab software. In addition, the data were filtered using a cascaded Butterworth filter, which eliminated noise and interference.

The water content of the samples was assessed by drying. The tests were carried out in accordance with PN-90/A-75101.03. At the outset, the prepared crucibles were half filled with pre-washed sea sand and then weighed. Approximately $3 \mathrm{~g}$ of a homogeneous plum sample was weighed into a weighing dish with an accuracy of $0.001 \mathrm{~g}$. Then the content was mixed. The sample was inserted into a Binder $115 \mathrm{~L}$ dryer with forced air circulation. Drying was carried out at $104^{\circ} \mathrm{C}$ until constant weight was obtained. After the process was completed, crucibles were placed in a desiccator for 60 minutes.

\section{Results and discussion}

Based on the created charts and results of physicochemical tests, it was determined that the fruit defrosting time depended on the amount of water contained in the fruit. Table 1 presents the results of experimental studies on the water content of fruits preserved by the dehydrofreezing method and defrosted in a vacuum-steam chamber.

Table 1.

Water content (\%) in fruits preserved by the dehydrofreezing method, defrosted by a vacuumsteam method

\begin{tabular}{lcccccc}
\hline \multirow{2}{*}{ The tested combination } & \multicolumn{7}{c}{ Freezing storage time (months) } \\
& 1 & 2 & 3 & 4 & 5 & 6 \\
\hline 0 & 89.97 & 89.88 & 89.54 & 89.07 & 88.89 & 88.63 \\
$35 \%, 1.5 \mathrm{~h}$ & 87.89 & 87.64 & 87.47 & 87.32 & 86.51 & 86.08 \\
$35 \%, 3 \mathrm{~h}$ & 87.27 & 87.02 & 86.98 & 86.23 & 85.91 & 85.44 \\
$45 \%, 1.5 \mathrm{~h}$ & 86.99 & 86.53 & 86.39 & 85.98 & 85.25 & 84.99 \\
$45 \%, 3 \mathrm{~h}$ & 86.21 & 85.87 & 85.61 & 85.06 & 84.58 & 84.42 \\
$55 \%, 1.5 \mathrm{~h}$ & 84.96 & 84.47 & 83.73 & 83.11 & 82.89 & 82.27 \\
$55 \%, 3 \mathrm{~h}$ & 83.33 & 82.93 & 82.26 & 81.96 & 81.51 & 81.08 \\
$65 \%, 1.5 \mathrm{~h}$ & 80.35 & 79.92 & 79.05 & 78.78 & 78.43 & 77.93 \\
$65 \%, 3 \mathrm{~h}$ & 77.91 & 76.87 & 76.24 & 75.25 & 75.00 & 74.91 \\
\hline
\end{tabular}

In all tested combinations of the osmotically dehydrated fruit, a significant reduction in defrosting time was observed, along with the time of storage freezing, and a decrease in water content. In plums dehydrated in $45-65 \%$ sucrose solutions, duration of the defrosting process was shortened already after three months of frozen storage. 


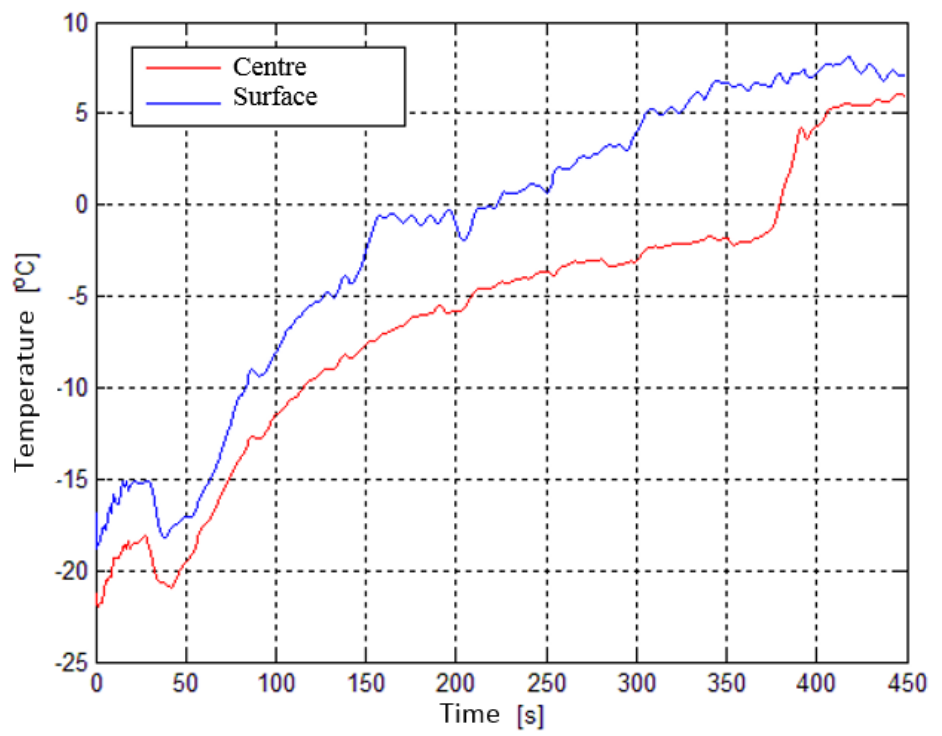

Figure 2. Timeframe of temperature changes in the geometric center of the sample and on its surface during vacuum-steam defrosting of non-dehydrated plums after 3 months of storage

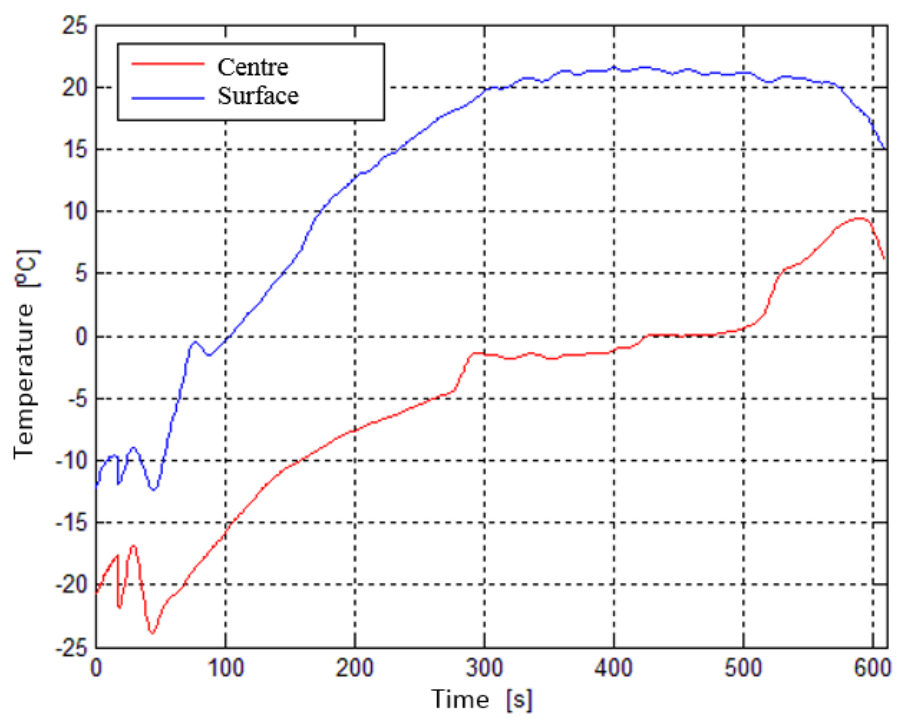

Figure 3. Timeframe of temperature changes in the geometric center of the sample and on its surface during vacuum-steam defrosting of non-dehydrated plums after 6 months of storage 
Agnieszka Szparaga, Sławomir Kocira, Alaa Subr, Ameer Al-Ahmadi

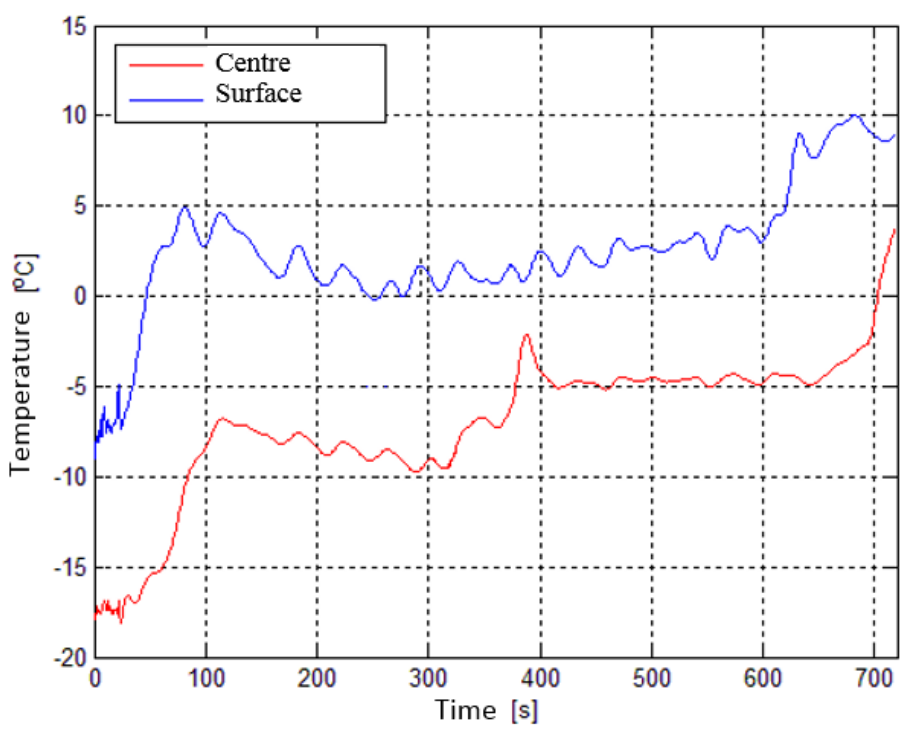

Figure 4. Timeframe of temperature changes in the geometric center of the sample and on its surface during vacuum-steam defrosting of dehydrated plums for 3 hours in a $45 \%$ sucrose solution, after 3 months of freezing storage

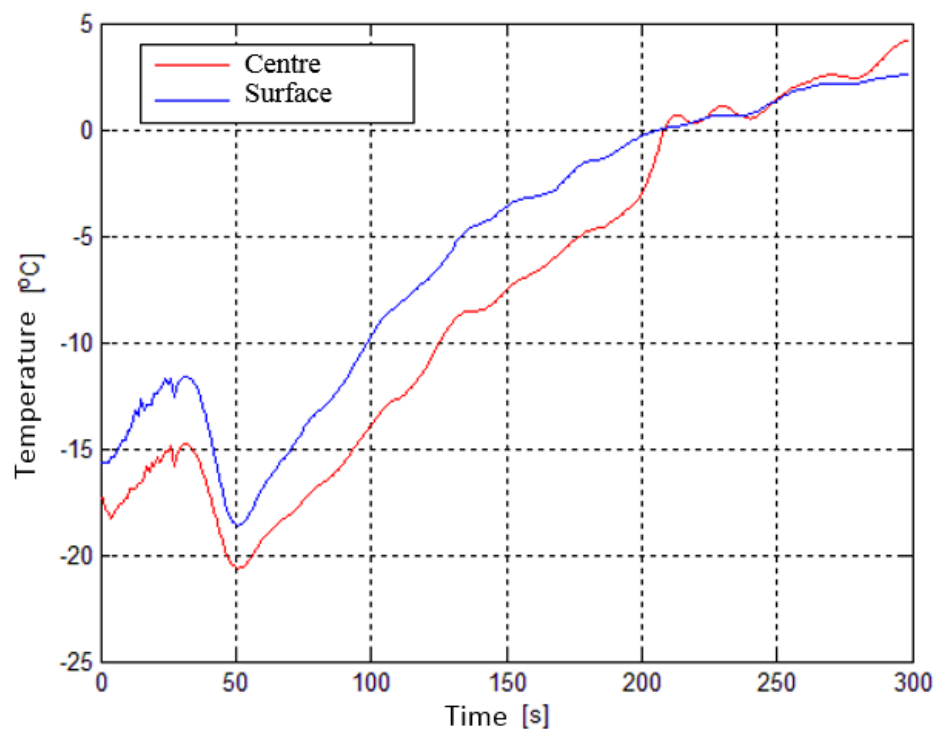

Figure 5. Timeframe of temperature changes in the geometric center of the sample and on its surface during vacuum-steam defrosting of dehydrated plums for 6 hours in a $45 \%$ sucrose solution, after 3 months of freezing storage 


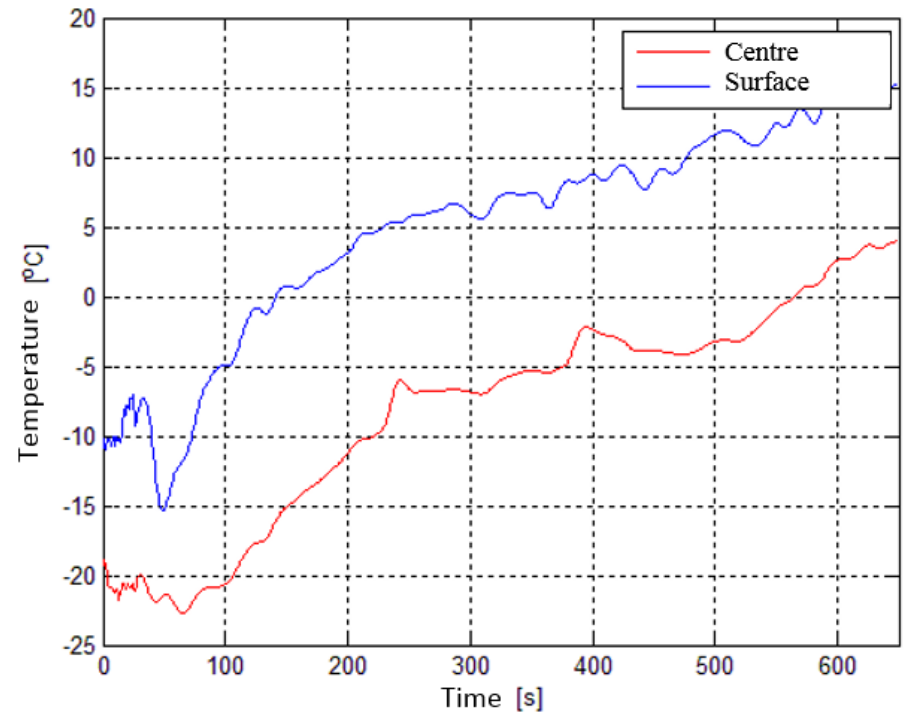

Figure 6. Timeframe of temperature changes in the geometric center of the sample and on its surface during vacuum-steam defrosting of dehydrated plums for 3 hours in a $65 \%$ sucrose solution, after 3 months of freezing storage

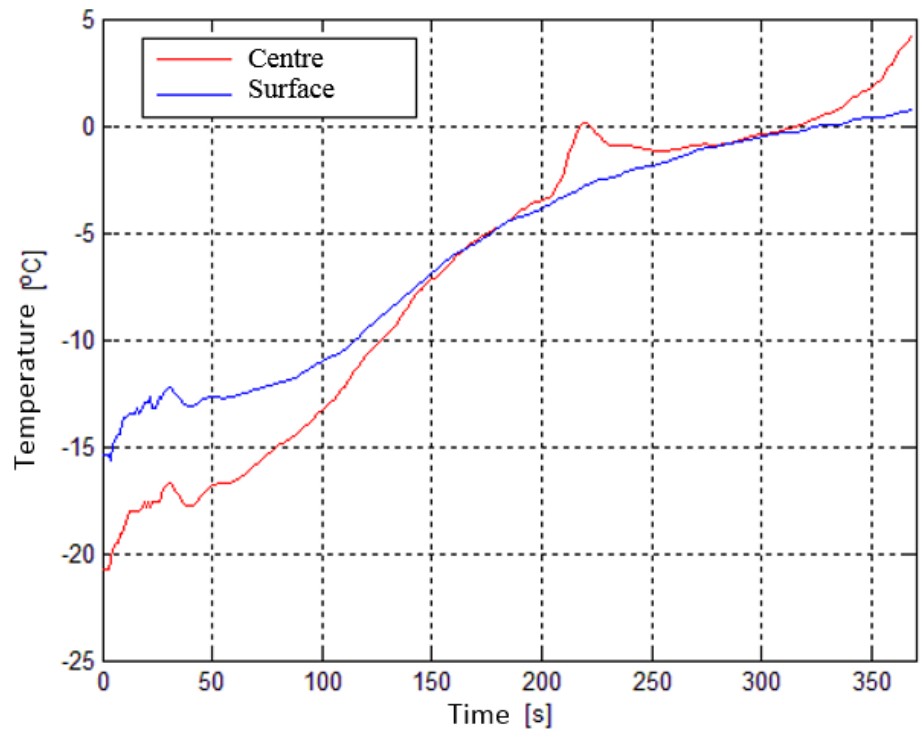

Figure 7. Timeframe of temperature changes in the geometric center of the sample and on its surface during vacuum-steam defrosting of dehydrated plums for 6 hours in a $65 \%$ sucrose solution, after 3 months of freezing storage 
After six months of storage, defrosting of fruit was twice as fast. Only in the case of plums frozen without prior dehydration an extension of the process time was observed due to the high water content, which was at a similar level during the freezing cycle. A similar tendency was noted for fruits in which the lowest concentration of the osmotic substance solution was used during initial treatment. The temperature fluctuations visible on the charts (2-7), both on the surface and in the center of the sample, were caused by cooling and then heating the water in the steam generator. The temperature change in the geometric center is characteristic of the defrosting process, with the heating stage, plateau period and heating stage being noted. The obtained courses of temperature changes confirm the results obtained by Diakun and Kopeć (2006), Kopeć and Diakun (2007) and Kopeć et al. (2009).

The solutions presented in the paper, innovative in terms of agricultural engineering, can be easily transferred to other plant raw materials fixed by the dehydrofreezing method (Bartosik et al., 2011), as well as to other agri-food product preservation technologies. What remains to be specified is the criteria and decision variables that are adequate to the problem under consideration. The search for and evaluation of new fixing process solutions is highly desirable.

\section{Conclusions}

1. Osmotic pre-treatment and freezing storage time ipacted the water content of plums, at the same time determining the course of the vacuum-steam defrosting process.

2. Increasing the osmotic solution concentration and dehydration time at the pre-treatment stage resulted in greater uniformity of defrosting samples, due to the decreasing difference between the surface temperature and the geometric center of the fruit.

3. The defrosting of fruit by the vacuum-steam method after 6 months of frozen storage was faster and more even, compared to the initial storage stages.

\section{References}

Agnelli, M.E., Marani, C.M., Mascheroni, R.H. (2005). Modelling of heat and mass transfer during (osmo) dehydrofreezing of fruits. Journal of Food Engineering, 69, 415-424.

Bartosik, P., Plawgo, A., Kukiełka, L. (2011). Optymalizacja statyczna procesu odwadniania osmotycznego i przechowywania truskawek. Inżynieria Rolnicza, 5(130), 15-21.

Chiralt, A., Talens,P. (2005). Physical and chemical changes induced by osmotic dehydration in plant tissues. Journal of Food Engineering, 67, 167-177.

Diakun, J., Kopeć, A. (2004). Koncepcja rozmrażania próżniowo - parowego produktów spożywczych z wykorzystaniem sublimacji. XI konferencja naukowo - techniczna BEMS. Wydawnictwo Uczelnianie Politechniki Koszalińskiej, Koszalin.

Diakun, J., Kopeć, A. (2006). Porównanie procesu rozmrażania mięsa metodami próżniowo-parową i sublimacyjno-próżniowo-parową. Inżynieria Rolnicza, 7(82), 73-81.

Gruda, Z., Postolski, J. (1999). Zamrażanie żywności, Warszawa, Wydawnictwa Naukowo-Techniczne. ISBN 8320423325.

Kamińska, A., Lewicki, P.P. (2005). Metoda dehydrofreezing (D-F) - znaczenie i przyszłość. Przemyst Spożywczy, 9, 12-15.

Kamińska, A., Lewicki, P.P. (2006). Metoda dehydrofreezing. Chłodnictwo XLI, 10, 38-42. 
Analysis of the vacuum-steam...

Konopacka, D. (2006). Produkcja suszu wiśniowego z wykorzystaniem technologii odwadniania osmotycznego. Przemyst Fermentacyjny i Owocowo-Warzywny, 11, 12-15.

Kopeć, A., Diakun, J. (2005). Kinetyka zmian masy i temperatury w procesie sublimacyjno-parowopróżniowego rozmrażania mięsa. Inżynieria Rolnicza 11(71), 251-258.

Kopeć, A., Diakun, J., Milewski, T. (2009). Rozmrażanie truskawek metodą próżniowo-parową. Inżynieria Rolnicza 2(111), 83-89.

Kowalska, H., Lenart, A. (1999). Kinetyka odwadniania osmotycznego jabłek i marchwi w wybranych parametrach procesu. Zeszyty Naukowe Politechniki Łódzkiej, Inżynieria Chemiczna i Procesowa, $821(25), 55-61$.

Kowalska, H., Lenart, A. (2005). Zmiany struktury tkanki roślinnej wywołane odwadnianiem osmotycznym. Inżynieria Rolnicza 9, 187-195.

Lazarides, H.N., Mavroudis, N. (1995). Freeze/thaw effect on mass transfer rates during osmotic dehydration. Journal of Food Science 60(4), 826-829.

Moreno, J., Chiralt, A., Escriche, I., Serra, J.A. (2000). Effect of blanching/osmotic dehydration combined methods on quality and stability of minimally processed strawberries. Food Research International, 33, 609-616.

Pałacha, Z., Kamińska, A. (2001). Wpływ wstępnej obróbki osmotycznej na przebieg procesu zamrażania jabłek. Chłodnictwo 36(3), 44-47.

Piotrowska, M., Nowak, A. (2005). Drobnoustroje w produktach spożywczych mrożonych i przechowywanych w warunkach chłodniczych. Chłodnictwo, 12, 50-52.

PN-90/A-75101.03. Przetwory owocowe i warzywne. Oznaczanie zawartości suchej masy metoda wagową.

\title{
ANALIZA PROCESU ROZMRAŻANIA ŚLIWEK W KOMORZE PRÓŻNIOW-PAROWEJ, UTRWALONYCH WSTĘPNIE METODĄ DEHYDROFREEZING
}

\begin{abstract}
Streszczenie: Materiałem badawczym były śliwki odmiany Węgierka Zwykła (Prunus domestica L.) Owoce poddano wstępnej obróbce osmotycznej, przy zmiennych parametrach czasu procesu oraz stężenia roztworu osmotycznego. Tak utrwalone śliwki zostały zamrożone i przechowywane przez 6 miesięcy. W równych odstępach czasu (co miesiąc) produkt był rozmrażany metodą próżniowo- parową, $\mathrm{z}$ zastosowaniem komory s-p-p, do momentu wskazania przez termoparę temperatury $4^{\circ} \mathrm{C}$ $\mathrm{w}$ centrum termicznym próbki. W celu zbadania kinetyki zachodzących zjawisk w czasie procesu rozmrażania, komora wyposażona była w układ pomiarowy, który umożliwił pomiar i rejestrację zmian w czasie temperatury w centrum geometrycznym próbki oraz temperatury na powierzchni próbki. Przeprowadzone badania dowiodły, że czas rozmrażania próżniowo - parowego owoców był zależny od ilości zawartej w nich wody. W śliwkach odwadnianych w roztworach sacharozy w zakresie stężeń 45-65\% już od trzeciego miesiąca zamrażalniczego przechowywania nastapiło skrócenie czasu procesu. Po 6 miesiącach przechowywania rozmrażanie tych owoców przebiegało 2-krotnie szybciej niż prób kontrolnych.
\end{abstract}

Słowa kluczowe: śliwki, komora, rozmrażanie, dehydrofreezing, proces 